\title{
PENGARUH KOMPENSASI DAN DISIPLIN KERJA TERHADAP KINERJA KARYAWAN PT PAMA PERSADA NUSANTARA DI SANGATTA-KUTAI TIMUR
}

\author{
Kaharuddin \\ Sekolah Tinggi Ilmu Manajemen Indonesia - Samarinda \\ Jl. Dr. Muhammad Yamin no 78 RT VII Samarinda 75119 \\ email : kahar_asa@yahoo.com
}

\begin{abstract}
The study tries to identify to what extent compensation and dicipline for work performance of employees PT Pama Persada. Analysis model used to prove hypothesis is model analysis multiple linier regression that be analysed with using statistics computer program package, that is SPSS v. 16.0 for Windows. Furthermore it was conducted examination for validity of data by multikolinieritas test, heteroskedastisitas test and autocorrelation test. Result of statistics analysis show that coefficient of the free variables regression, that is involvement factor in compensation $(\mathrm{X} 1)=0,059$, dicipline $(\mathrm{X} 2)=$ 0,743 , and constanta equal to 0,697 . Equation of multiple linier regression is: $\mathrm{Y}=0,697$ $+0,059 \mathrm{X} 1+0,743 \mathrm{X} 2$

Conclusion that receive that level of influence explained by compensation, dicipline are as independent variable impact toward performance of employees PT Pama Persada equal to correlation coefficient (R), that is 0,766 and level of depended performance to second of free variables above is equal to determination coefficient value $\left(\mathrm{R}^{2}\right)$ that is 0,587 or $58,7 \%$. Result of analysis $\mathrm{F}$ - test indicate that all free variables by together have significant influence toward performance of employees PT Pama Persada. Variabel independent has dominant influence to performance of employees PT Pama Persada is discipline.
\end{abstract}

\section{Pendahuluan}

Sangatta merupakan salah satu kabupaten Kutai Timur yang memiliki sumber daya alam sangat potensial. Salah satu sumber daya alam yang ada di Sangatta adalah batu bara. Kaltim Prima Coal merupakan salah satu perusahaan pertambangan batu bara yang memiliki ijin dari pemerintah kabupaten Kutai Timur untuk melakukan penambangan di wilayah Sangatta. Perusahaan Kaltim Prima Coal (KPC) bekerja sama dengan beberapa perusahaan lain sebagai kontraktor dalam melaksanakan pekerjaannya. Perusahaan kontraktor yang ada di Sangatta antara lain : PT Thiess Indonesia, PT Darma Henwa, PT Madhani, PT PIK, dan PT Pama Persada. PT Pama Persada a yang menjadi objek penelitian adalah perusahaan yang bergerak dibidang pertambangan batubara yang ada di wilayah Indonesia. PT Pama Persada memiliki beberapa Departemen, salah satunya, yaitu Departemen Engineering yang memiliki tiga Section yang mempunyai tugas dan peran penting dalam proses penambangan. Pertama, adalah Section Mine Plan. PT Pama Persada berkeinginan memiliki karyawan dengan kinerja yang baik. Menurut Mangkunegara (2001) kinerja adalah hasil kerja secara kualitas dan kuantitas yang dapat dicapai oleh seorang pegawai dalam melaksanakan tugas sesuai dengan tanggung jawab yang diberikan kepadanya. Kinerja pegawai merupakan salah satu faktor terpenting dalam mencapai tujuan yang diharapkan oleh perusahaan, jika kinerja karyawan buruk maka produktivitas perusahaan juga akan berkurang, tetapi jika kinerja karyawan baik produktivitas yang diharapkan akan mudah tercapai. 
Kinerja memiliki arti suatu hasil kerja yang dapat dicapai oleh seseorang atau sekelompok orang dalam suatu organisasi sesuai dengan wewenang dan tanggung jawab masing-masing. Kinerja karyawan yang baik secara langsung akan mempengaruhi kinerja perusahaan. Sumber daya manusia sebagai aktor yang berperan aktif dalam menggerakkan organisasi dalam mencapai tujuannya. Tercapainya tujuan organisasi hanya dimungkinkan karena upaya para pelaku yang terdapat dalam organisasi, untuk berkinerja dengan baik. Kinerja perorangan (individual performance) dengan kinerja organisasi (corporate performance) terdapat hubungan yang erat. Dengan perkataan lain bila kinerja karyawan (individual performance) baik maka kemungkinan besar kinerja organisasi (corporate performance) juga baik. Kinerja karyawan akan baik bila ia mempunyai keahlian (skill) yang tinggi, bersedia bekerja karena gaji atau diberi upah yang sesuai dengan perjanjian dan mempunyai harapan masa depan yang lebih baik (Prawirosentono,1999). Menurut Mathis dan Jackson (2002) kinerja pada dasarnya adalah apa yang dikerjakan dan yang tidak dikerjakan oleh karyawan. Kinerja karyawan mempengaruhi seberapa banyak mereka memberikan kontribusi kepada organisasi. Mathis dan Jackson (2002) lebih lanjut memberikan standar kinerja sesorang yang dilihat kuantitas output, kualitas output, jangka waktu output, kehadiran di tempat kerja dan sikap kooperatif. Standar kinerja tersebut ditetapkan berdasarkan kriteria pekerjaan yaitu menjelaskan apa-apa saja yang sudah diberikan organisasi untuk dikerjakan oleh karyawannya, oleh karena itu kinerja individual dalam kriteria pekerjaan haruslah diukur, dibandingkan dengan standar yang ada dan hasilnya harus dikomunikasikan kepada seluruh karyawan. Mathis dan Jackson (2002) juga menjelaskan standar kinerja dapat berupa output produksi atau lebih dikenal dengan standar kinerja numerik dan standar kinerja non numerik. Kinerja merupakan hasil dan keluaran yang dihasilkan oleh seorang karyawan sesuai dengan perannya dalam organisasi dalam suatu periode tertentu. Kinerja karyawan yang baik adalah salah satu faktor yang sangat penting dalam upaya instansi untuk meningkatan produktivitas. Kinerja merupakan indikator dalam menentukan bagaimana usaha untuk mencapai tingkat produktivitas yang tinggi dalam suatu organisasi atau instansi. Perusahaan melakukan usaha - usaha untuk meningkatkan kinerja para karyawannya. Perusahaan melakukan beberapa tahapan-tahapan untuk meningkatkan kinerja karyawan, pembinaan dan pelatihan adalah tahap awal untuk meningkatkan kinerja karyawan dan tahap akhir yang dilakukan oleh perusahaan adalah tahapan penilaian yang bertujuan untuk mengetahui tingkat kinerja karyawan. Salah satu usaha pembinaan yang dilakukan dalam rangka peningkatan kinerja karyawan adalah ditingkatkannya disiplin kerja karyawan. Menurut Sastrohadiwiryo (2001) disiplin kerja dapat didefinisikan sebagai suatu sikap menghormati, menghargai, patuh dan taat terhadap peraturan-peraturan yang berlaku, baik yang tertulis maupun tidak tertulis serta sanggup menjalankannya dan tidak mengelak menerima sanksi-sanksinya apabila ia melanggar tugas dan wewenang yang diberikan kepadanya.

Disiplin sangat penting untuk pertumbuhan organisasi, digunakan terutama untuk memotivasi karyawan agar dapat mendisiplinkan diri dalam melaksanakan pekerjaan baik secara perorangan maupun kelompok. Disamping itu disiplin bermanfaat mendidik karyawan untuk mematuhi dan menyenangi peraturan, prosedur, maupun kebijakan yang ada, sehingga dapat menghasilkan kinerja yang baik. Disiplin tidak hanya dalam bentuk ketaatan saja melainkan juga tanggung jawab yang diberikan oleh organisasi, berdasarkan pada hal tersebut diharapkan efektifitas karyawan akan meningkat dan bersikap serta bertingkah laku disiplin. Kedisiplinan karyawan dapat ditegakkan apabila peraturanperaturan yang telah ditetapkan itu dapat diatasi oleh sebagian besar karyawannya dalam kenyataan, bahwa dalam suatu instansi apabila sebagian besar karyawannya mentaati segala peraturan yang telah ditetapkan, maka disiplin karyawan sudah dapat ditegakkaan. 
Keteraturan adalah ciri utama organisasi dan disiplin adalah salah satu metode untuk memelihara keteraturan tersebut. Tujuan utama disiplin adalah untuk menigkatkan efisiensi semaksimal mungkin dengan cara mencegah pemborosan. Singkatnya, disiplin dibutuhkan untuk tujuan organisasi yang lebih jauh, guna menjaga efisiensi dengan mencegah dan mengoreksi tindakan-tindakan individu dalam iktikad tidak baiknya terhadap kelompok. Lebih jauh lagi, disiplin berusaha untuk melindungi perilaku yang baik dengan menetapkan respons yang dikehendaki (Tohardi, 2002). Disiplin kerja dapat dilihat sebagai sesuatu yang besar manfaatnya, baik bagi kepentingan organisasi maupun bagi karyawannya. Bagi organisasi adanya disiplin kerja akan menjamin terpeliharanya tata tertib dan kelancaran pelaksanaan tugas, sehingga di peroleh hasil yang optimal. Adapun bagi pegawai akan diperoleh suasana kerja yang menyenangkan sehingga akan menambah semangat kerja dalam melaksanakan pekerjaannya. Menurut Sukarno (1994) disiplin karyawan memainkan peranan yang dominan, krusial, dan kritikal dalam keseluruhan upaya untuk meningkatkan produktivitas kerja para karyawan. Disiplin kerja para karyawan sangat penting. Disiplin kerja merupakan hal yang harus ditanamkan dalam diri tiap karyawan, karena hal ini akan menyangkut tanggung jawab moral karyawan itu pada tugas kewajibannya. Seperti juga suatu tingkah laku yang bisa dibentuk melalui kebiasaan. Selain itu, disiplin kerja dapat ditingkatkan apa bila tedapat kondisi kerja yang dapat merangsang karyawan untuk berdisiplin. Penelitian yang dilakukan oleh Astri Yudha (2011) membuktikan bahwa disiplin kerja berpengaruh positif signifikan terhadap kinerja karyawan. Artinya semakin baik disiplin kerja yang dilakukan oleh karyawan maka kinerja karyawan juga semakin baik.

Selanjutnya usaha lain untuk meningkatkan kinerja karyawan, diantaranya adalah dengan memperhatikan kompensasi. Kompensasi yang diberikan secara benar akan berpengaruh pada para karyawan lebih terpuaskan dan termotivasi untuk mencapai sasaran-sasaran organisasi. Menurut Hasibuan (2013) kompensasi kerja adalah semua pendapatan yang berbentuk uang, barang langsung atau tidak langsung yang diterima karyawan sebagai imbalan balas jasa yang diberikan kepada perusahaan. Kompensasi merupakan fungsi strategi sumber daya manusia yang mempunyai imbas signifikan atas fungsi-fungsi sumber daya manusia lainnya. Kompensasi sangat berpengaruh terhadap kinerja karyawan, jika sebuah kinerja itu dihargai dengan sebuah kompensasi maka kepuasan karyawan akan tercapai. Menurut Rivai (2006) kompensasi karyawan adalah seluruh imbalan yang diterima karyawan atas hasil kerja karyawan pada perusahaan atau organisasi. Kompensasi ini bisa berupa fisik atau non fisik, harus dihitung dan diberikan kepada karyawan sesuai dengan pengorbanan yang telah diberikannya kepada perusahaan atau organisasi tempat ia bekerja. Hasil penelitian yang dilakukan Nadya Wahyuningtiyas (2013), kompensasi berpengaruh positif dan signifikan terhadap kinerja karyawan, artinya semakin baik kompensasi yang diterima oleh karyawan maka kinerja karyawan juga semakin baik. Besar kecilnya kompensasi dapat mempengaruhi kinerja karyawan. Apabila kompensasi diberikan secara tepat dan benar para karyawan akan memperoleh kepusan kerja dan termotivasi untuk mencapai tujuan-tujuan perusahaan, Rivai (2006). Apabila kompensasi itu diberikan tidak memadai atau kurang tepat, prestasi, motivasi, dan kepuasan kerja karyawan akan menurun. Kompensasi bukan hanya penting untuk para karyawan saja, melainkan juga penting bagi organisasi itu sendiri, karena programprogam kompensasi merupakan pencerminan agar organisasi dapat mempertahankan sumber daya manusia. Karyawan PT Pama Persada menjadi aset perusahaan yang harus di perhatikan, sehingga perusahaan tidak kehilangan karyawan-karyawan yang berprestasi dan memiliki kinerja yang baik. Dalam pengamatan sementara, objek penelitian penulis mengenai kinerja karyawan PT. Pama Persada masih belum optimal. Adapun masalah dari hal tersebut adalah masih ada karyawan yang tidak bekerja pada hari kerja dan 
adanya karyawan yang menuntut kenaikan kompensasi walaupun terjadi pengurangan jam kerja, karena menurut mereka kebutuhan hidup tiap tahun selalu meningkat. Hal ini menyebabkan karyawan merasa kurang puas terhadap apa yang mereka terima selama mereka bekerja. PT. Pama Persada mengurangi jam kerja dikarenakan kondisi perekonomian yang menurun yang disebabkan secara drastis. Pimpinan PT. Pama Persada membuat kebijakan tidak melakukan pemutusan hubungan kerja, tetapi pengurangan jam kerja. Hal tersebut dimaksudkan agar karyawan tetap memiliki pekerjaan dan mendapat penghasilan. Akan tetapi kebijakan perusahaan tersebut tidak sesuai dengan yang diharapkan oleh karyawan. Fakta di lapangan membuktikan bahwa pengurangan jam kerja berdampak terhadap penurunan kompensasi membuat karyawan banyak yang melanggar disiplin kerja, seperti : terlambat masuk kerja, istirahat sebelum jam istirahat yang telah ditentukan, sering menolak tugas yang seharusnya dilakukan.

2. Kajian Literatur

$2.1 \quad$ Kompensasi

Menurut Panggabean (2004) kompensasi dapat didefinisikan sebagai setiap bentuk penghargaan yang diberikan kepada karyawan sebagai balas jasa atas kontribusi yang mereka berikan kepada organisasi, sedangakan menurut Hasibuan (2013) kompensasi adalah semua pendapatan yang berbentuk uang, barang langsung atau tidak langsung yang diterima karyawan sebagai imbalan balas jasa yang diberikan kepada perusahaan. Kompensasi merupakan bentuk penghargaan atau balas jasa yang diberikan oleh perusahaan kepada karyawannya baik yang berbentuk finansial maupun barang dan jasa pelayanan agar karyawan merasa dihargai dalam bekerja. Pemberian kompensasi merupakan salah satu pelaksanaan fungsi MSDM yang berhubungan dengan semua jenis pemberian penghargaan individual sebagai pertukaran dalam melakukan tugas organisasi. 2.2 Disiplin Kerja

Disiplin menurut T. Hani Handoko (2001) adalah kegiatan manajemen untuk menjalankan standar-standar organisasional. Sedangkan menurut Alfred R. Lateiner dan I.S. Levine (Soedjono,1980) disiplin merupakan suatu kekuatan yang selalu berkembang di tubuh para pekerja yang membuat mereka dapat mematuhi keputusan dan peraturanperaturan yang telah ditetapkan. Menurut Drs. H. Malayu S.P. Hasibuan (2013) disiplin yang baik mencerminkan besarnya rasa tanggung jawab seseorang terhadap tugas-tugas yang diberikan kepadanya. Hal ini mendorong gairah kerja, semangat kerja, dan terwujudnya tujuan perusahaan, karyawan, dan masyarakat. Jadi seseorang akan bersedia mematuhi semua peraturan serta melaksanaan tugas-tugasnya, baik secara sukarela maupun karena terpaksa. Disiplin bisa dikatakan berjalan dengan baik jika karyawan selalu datang dan pulang tepat pada waktunya, mengerjakan pekerjaanya dengan baik, mematuhi semua peraturan perusahaan dan norma-norma sosial yang berlaku.

2.3. Kinerja Karyawan

Menurut Bernardin dan Russel (2003) kinerja adalah catatan tentang hasil-hasil yang diperoleh dari fungsi-fungsi pekerjaan tertentu atau kegiatan selama kurun waktu tertentu. Sedangkan menurut Maluyu S.P. Hasibuan (2000) kinerja adalah suatu hasil kerja yang dicapai seseorang dalam melaksanakan tugas-tugas yang dibebankan kepadanya yang didasarkan atas kecakapan, pengalaman, dan kesungguhan serta waktu.

3. Hipotesis

Hipotesis merupakan pernyataan singkat yang disimpulkan dari landasan teori dan penelitian terdahulu, serta merupakan jawaban sementara terhadap masalah yang diteliti, dimana jawaban itu masih bersifat lemah, dan perlu dilakukan pengujian secara empiris kebenarannya. Adapun hipotesis yang diajukan dalam penelitian ini adalah sebagai berikut: 


\section{Ha: Kompensasi dan Disiplin Kerja Berpengaruh Terhadap Kinerja Karyawan.}

H0: Kompensasi dan Disiplin Kerja Tidak Berpengaruh Terhadap Kinerja Karyawan.

4. Metode Penelitian

4.1. Identifikasi Variabel Penelitian

Variabel penelitian dalam penelitian ini adalah :

a. Independent Variable (Variabel bebas). Tipe variabel yang mempengaruhi variabel lain atau variabel yang mempengaruhi variabel terikat. Dalam penelitian ini Independent Variable adalah Kompensasi (XI) dan Disiplin Kerja (X2).

b. Dependent Variable (Variabel Terikat). Tipe variabel yang dipengaruhi oleh variabel lain atau variabel yang dipengaruhi oleh variabel bebas. Dalam penelitian ini Dependent Variable adalah Kinerja Karyawan (Y)

\subsection{Definisi Operasional}

Menurut Widayat dan Amirullah (Purnamasari, 2008) definisi operasional variabel merupakan suatu definisi yang diungkapkan secara jelas dari masing-masing variabel dalam penelitian, dan dijabarkan ke dalam indikator-indikator. Indikator adalah dimensi tertentu dari suatu konsep yang dapat diukur (Widiyanto, 2008). Adapun definisi operasional variabel dalam penelitian ini :

Tabel.1

Variabel Penelitian dan Definisi Operasional

\begin{tabular}{|c|c|c|c|}
\hline Variabel & Definisi Operasional & Sumber & Indikator \\
\hline $\begin{array}{l}\text { Kinerja } \\
\text { (Y) }\end{array}$ & $\begin{array}{l}\text { Kinerja adalah } \\
\text { catatan tentang hasil- } \\
\text { hasil yang diperoleh } \\
\text { dari fungsi-fungsi } \\
\text { pekerjaan tertentu } \\
\text { atau kegiatan selama } \\
\text { kurun waktu tertentu }\end{array}$ & $\begin{array}{l}\text { Bernardin \& } \\
\text { Russel (2003) }\end{array}$ & $\begin{array}{l}\text { a. Kualitas } \\
\text { b. Kuantitas } \\
\text { c. Ketepatan Waktu } \\
\text { d. Efektifitas } \\
\text { e. Hubungan antar } \\
\text { persorangan }\end{array}$ \\
\hline Kompensasi (X1) & $\begin{array}{l}\text { Kompensasi adalah } \\
\text { semua pendapatan } \\
\text { yang berbentuk uang, } \\
\text { barang langsung atau } \\
\text { tidak langsung yang } \\
\text { diterima karyawan } \\
\text { sebagai imbalan alas } \\
\text { jasa yang diberikan } \\
\text { kepada perusahaan }\end{array}$ & $\begin{array}{l}\text { Hasibuan } \\
(2013)\end{array}$ & $\begin{array}{l}\text { a. Gaji } \\
\text { b. Insentif } \\
\text { c. Asuransi } \\
\text { d. Fasilitas kantor } \\
\text { e. Tunjangan }\end{array}$ \\
\hline
\end{tabular}




\begin{tabular}{|c|c|c|c|}
\hline Disiplin Kerja (X2) & $\begin{array}{lr}\text { Disiplin } & \text { kerja } \\
\text { merupakan } & \text { suatu } \\
\text { kekuatan yang } & \text { selalu } \\
\text { berkembang di tubuh } \\
\text { para pekerja yang } \\
\text { membuat mereka } \\
\text { dapat mematuhi } \\
\text { keputusan dan } \\
\text { peraturan - peraturan } \\
\text { yang telah ditetapkan }\end{array}$ & $\begin{array}{l}\text { Leitner \& } \\
\text { Levine }(1980)\end{array}$ & $\begin{array}{l}\text { a. Adanya ketaatan } \\
\text { pegawai terhadap } \\
\text { peraturan jam kerja. } \\
\text { b. Ketaatan pegawai } \\
\text { terhadap pakaian } \\
\text { kerja. } \\
\text { c. Menggunakan dan } \\
\text { menjaga } \\
\text { perlengkapan kantor } \\
\text { d. Kuantitas dan kualitas } \\
\text { hasil kerja sesuai } \\
\text { dengan standar. } \\
\text { e. Adanya semangat } \\
\text { pegawai dalam } \\
\text { bekerja. }\end{array}$ \\
\hline
\end{tabular}

Untuk menentukan nilai masing-masing varibel, jawaban diukur dengan scoring berdasarkan skala likert. Nilai skor tertinggi adalah 5 dan terendah adalah 1. Penentuan skor ini berdasarkan pada pendapat Nur Indriantoro dan Bambang Supomo (1999;17) bahwa seorang peneliti dalam menentukan skor ada yang mengemukakan jenjang $3(1,2,3)$, jenjang $5(1,2,3,4,5)$ dan jenjang 7 $(1,2,3,4,5,6,7)$.

Proses pemberian skor pada varibel-variabel penelitian ini adalah sebagai berikut

1) Skor 1 adalah kategori sangat tidak sesuai

2) Skor 2 adalah kategori tidak sesuai

3) Skor 3 adalah kategori cukup

4) Skor 4 adalah kategori sesuai

5) Skor 5 adalah kategori sangat sesuai

Untuk mendapatkan kelas interval dalam pengelompokan dari scoring 1 sampai dengan 5, dilakukan dengan cara menghitung nilai rata-rata dari masing masing responden. Interval dihitung dengan rumus :

\section{$\underline{\text { Nilai tertinggi }- \text { Nilai terendah }}=\underline{5-1}=0,8$}

$$
\text { Jumlah Kelas }{ }_{\text {nilai }}^{5} \text { interval tersebut, }
$$

Berdasarkan nilai interval tersebut, maka dapat dibuat kelas interval distribusi kriteria pendapat dari responden sebagai berikut :

1) $1,00-<1,80=$ sangat tidak sesuai

2) $1,80-<2,60=$ tidak sesuai

3) $2,60-<3,40=$ cukup

4) $3,40-<4,20=$ sesuai

5) $4,20-<5,00=$ sangat sesuai

4.3 Waktu dan Lokasi Penelitian

Penelitian dilakukan di perusahaan PT. Pama Persada Tahun 2015

\subsection{Sumber Data}

Jenis data yang digunakan adalah data kualitatif yang diperoleh dari pengumpulan data primer dan sekunder melalui metode observasi dan kuisioner.

1. Data primer 
Pengumpulan data secara langsung dengan metode kuesioner (daftar pertanyaan dan interview (wawancara) kepada responden. Data primer tersebut adalah kompensasi dan disiplin kerja.

2. Data sekunder

Pengumpulan data sekunder diperoleh dari PT. Pama Persada yaitu dengan metode pencarian data melalui buku laporan tahunan dan mengakses data internet.

4.5 Populasi dan Sampel

Menurut Kuncoro $(2003 ; 103)$ dalam bukunya Metode Riset Untuk Bisnis dan Ekonomi : Bagaimana menulis dan meneliti skripsi mengatakan populasi adalah kelompok elemen yang lengkap yang biasanya berupa orang, objek, transaksi atau kerjadian dimana kita tertarik untuk mempelajarinya atau menjadikan objek penelitian. Populasi penelitian ini berjumlah 100 orang karyawan PT. Pama Persada mulai dari grade A terendah sampai survey Section Head. Penelitian ini melibatkan semua karyawan yang ada didalam departemen tersebut.

4.6 Teknik Pengumpulan Data

Didalam penelitian ini, peneliti menggunakan teknik pengumpulan data sebagai berikut :

1. Kuesioner

Teknik pengumpulan data dengan menggunakan daftar pertanyaan yang dijawab oleh responden.

2. Observasi

Pengamatan langsung ke objek yang menjadi pusat penelitian guna mendapatkan dan mengumpulkan data yang diperlukan dalam penelitian dan penulisan skripsi ini.

3. Penelitain dokumen

Penelitian dengan memeriksa dokumen-dokumen catatan atau file dari bank data karyawan yang ada hubungannya dengan penelitian ini.

4. Wawancara

Melakukan pembicaraan secara langsung kepada para petugas yang ada dilokasi penelitian untuk mendapatkan atau memperoleh petunjuk-petunjuk, keteranganketerangan yang dapat melengkapi data yang ada.

4.7 Teknik Analisis dan Pengujian Hipotesis

Untuk mengetahui besarnya hubungan antara variabel-variabel bebas (X) terhadap variabel terikat $(\mathrm{Y})$ atau untuk mengetahui sejauh mana varibel-variabel bebas (X) berpengaruh terhadap variabel terikat $(\mathrm{Y})$ dan disamping itu karena menggunakan variabel bebas lebih dari satu, maka model analisis yang digunakan adalah model regresi linier berganda.

$$
\text { Dimana: } \begin{aligned}
\mathrm{Y} & =\mathrm{a}+\mathrm{b} 1 \mathrm{X} 1+\mathrm{b} 2 \mathrm{X} 2+\mathrm{e} \\
\mathrm{Y} & =\text { kinerja karyawan } \\
\mathrm{X} 1 & =\text { kompensasi } \\
\mathrm{X} 2 & =\text { disiplin kerja } \\
\mathrm{a} & =\text { konstanta } \\
\mathrm{b} 1, \mathrm{~b} 2 & =\text { koef regresi } \\
\mathrm{e} & =\text { error/kesalahan }
\end{aligned}
$$

1. Teknik Analisis

Teknik analisis yang dilakukan dalam penelitian ini adalah menggunakan analisis kuantitatif. Data dianlisis dengan menggunakan model analisis regresi berganda dengan bantuan program SPSS 16 dengan langkah sebagai berikut :

a) Menetukan koefisien regresi untuk masing-masing varibel bebas multiple korelasi (R) untuk masing masing variabel bebas $(\mathrm{X})$ terhadap variabel tergantung $(\mathrm{Y})$.

b) Korelasi parsial (r) untuk setiap variabel bebas (X)

Hasil uji $\mathrm{F}$ dan uji $\mathrm{t}$ 
c) Tingkat probabilitas masing masing-masing variabel

Jika $\mathrm{R}^{2}$ hasilnya mendekati 0 (nol), maka pengaruhnya lemah secara umum, dapat dikatakan bahwa besarnya suatu koefisien determinasi $\left(\mathrm{R}^{2}\right)$ berada antara 0 dan 1 atau $0<$ $\mathrm{R}^{2}<1$. Koefisien determinasi adalah salah satu nilai statistic yang dapat digunakan untuk mengetahui apakah ada hubungan antara dua variabel. Menurut Alfigari $(2004 ; 45)$, nilai koefisien determinasi menunjukkan presentase variasi nilai dependen variabel yang dapat dijelaskan oleh persamaan regresi yang dihasilkan. Sedangkan koefisien korelasi (R) merupakan ukuran yang dapat digunakan untuk mengetahui bagaimana keeratan suatu variabel dengan variabel lain.

2. Pengujian hipotesis

Untuk mengetahui apakah hipotesis pertama yang diajukan ditolak atau ditrima makan dilakukan melalui uji F sebagai berikut :

a) Pengujian hipotesis pertama menggunakan uji $\mathrm{F}$ yaitu digunakan untuk mengetahui apakah secara simultan koefisien regresi variabel independen mempunyai pengaruh atau tidak terhadap variabel dependen. Pengujian hipotesis dilakukan dengan tingkat kepercayaan $95 \%(\alpha=5)$ Kriteria hipotesis :

Ho : b1 : b2 =0

Ha : b1 : b2 $\neq 0$

Apabila nilai $\mathrm{F}$ hitung lebih besar dari pada $\mathrm{F}$ tabel, maka hipotesis 0 (Ho) ditolak dan Hipotesis alternatif (Ha) diterima.

b) Pengajuan hipotesis kedua dilakukan dengan uji t, yaitu untuk menguji pengaruh variabel bebas secara terpisah terhadap varibel tidak bebas.

Kriteria hipotesis :

Ho : $\mathrm{b} 1=0$

$\mathrm{Ha}: \mathrm{b} 1 \neq 0$

Apabila nilai t hitung lebih besar dari t Tabel, maka hiotesis 0 (Ho) ditolak dan hipotesis alternatif Ha diterima. Untuk melihat pengaruh dominan yang berasal dari uji t dengan melihat standar koefisien beta terbesar.

3. Pengujian asumsi klasik

Pengujian terhadap asumsi klasik yaitu pengujian dengan asumsi yang mendasari pelakasanaan regresi linier berganda supaya hasilnya dapat diandalkan, maka perlu diuji multi kolinieritas, heteroskedasitas dan aotukorelasi.

a) Uji Multikolinieritas

Menurut Ghozali (2005;91), uji multikolinieritas bertujuan untuk mengetahui apakah pada model regresi ditemukan adanya korelasi antar variabel bebas (independen). Model regresi yang baik seharusnya tidak terjadi korelasi diantara variabel independen. Untuk mendeteksi terjadinya multikolinieritas dapat dilihat berdasarkan hasil varian inflation factor (VIF). Nilai cutoff yang umum dipakai untuk menunjukkan adanya multikolinieritas adalah niali-nilai toleransi $<0,10$ atau sama dengan nilai VIF $>10$.

b) Uji Heteroskedasititas

Menurut Ghozali (2005; 95) uji heteroskedasititas digunakan menguji dalam model regresi terjadi ketidaksamaan varian dari residual satu pengamatan ke pengamatan yang lain. Untuk mendeteksi ada atau tidaknya heteroskedisitas yaitu melihat penyebaran dari varian residualnya.

c) Uji Autokorelasi

Autokorelasi merupakan suatu gejalan adanya adanya korelasi diantara semua variabel dari serangkaian observasi yang disusun menurut urutan waktu, juga adanya korelasi variabel pengganggu (disturbance error). Untuk mengetahui ada 
atau tidaknya gejala autokorelasi, digunakan cara melakukan pengujian secara rutin atau seri dalam menghitung residu yang ditaksir dalam analisis regresi. Uji gejala ini sangat diperlukan pada penelitian eksperimen. Sedangkan penelitian ini beripa expost-facto sehingga disini tidak dibuktikan secara terinci. Menurut Imam Ghozali dalam bukunya Aplikasi Analisis Multivariate dengan program SPSS (2005;96), pendekatan dalam masalah autokorelasi dilakukan dengan menggunakan uji Durbin - Watson (DW Test). Menurut Algifari dalam bukunya Statistika Induktif $(2000 ; 89)$, untuk mengadopsi adanya suatu model regresi dilakukan dengan uji Durbin Watson (Uji DW) dengan ketentuan sebagai berikut

Tabel.2

Autokorelasi

\begin{tabular}{|c|c|}
\hline DW & Kesimulan \\
\hline$<1,08$ & Ada autokorelasi \\
\hline $1,08-1,66$ & Tanpa kesimpulan \\
\hline $1,66-2,34$ & Tidak ada autokorelasi \\
\hline $2,34-2,92$ & Tanpa kesimpulan \\
\hline$>2,92$ & Ada autokorelasi \\
\hline
\end{tabular}

5. Hasil Penelitian dan Pembahasan

Tabel.3

Uji Validitas

\begin{tabular}{|ll|r|r|r|}
\hline & \multicolumn{1}{|c|}{$\mathrm{Y}$} & \multicolumn{1}{c|}{$\mathrm{X} 1$} & \multicolumn{1}{c|}{$\mathrm{X} 2$} \\
\hline $\mathrm{Y}$ & Pearson Correlation & 1 & .305 & $.761^{* *}$ \\
& Sig. (2-tailed) & & .070 & .000 \\
& $\mathrm{~N}$ & 36 & 36 & 36 \\
\hline $\mathrm{X} 1 \quad$ Pearson Correlation & .305 & 1 & .284 \\
& Sig. (2-tailed) & .070 & & .094 \\
& $\mathrm{~N}$ & 36 & 36 & 36 \\
\hline $\mathrm{X} 2$ & Pearson Correlation & $.761^{* *}$ & .284 & 1 \\
& Sig. (2-tailed) & .000 & .094 & \\
& $\mathrm{~N}$ & 36 & 36 & 36 \\
\hline
\end{tabular}

**. Correlation is significant at the 0.01 level (2-tailed).

Sumber: Data hasil olahan SPSS, 2016

Uji Validitas ini untuk mengetahui apakah data yang berada dikuesioner sudah valid atau belum. Tabel V.1 menjelaskan bahwa variabel kompensasi, disiplin kerja, kinerja adalah valid. Hal ini ditunjukan dari $\mathrm{r}$ (korelasi) masing-masing variabel lebih besar dari pada 0,3 . 
Tabel.4

Uji Reliability

\begin{tabular}{|ll|r|r|}
\hline & & \multicolumn{1}{|c|}{$\mathrm{N}$} & \multicolumn{1}{|c|}{$\%$} \\
\hline Cases & Valid & 36 & 100.0 \\
& Excluded $^{\mathrm{a}}$ & & 0 \\
& Total & 36 & 100.0 \\
\hline
\end{tabular}

a. Listwise deletion based on all variables in the procedure.

Reliability Statistics

\begin{tabular}{|r|r|}
\hline $\begin{array}{c}\text { Cronbach's } \\
\text { Alpha }\end{array}$ & N of Items \\
\hline .635 & 3 \\
\hline
\end{tabular}

Sumber:Data hasil olahan SPSS, 2016

Dari tabel reabilitas menujukan bahwa variabel kompensasi disiplin kerja kinerja dapat diterima karena alpha lebih besar dari pada 0,6

Tabel.5

Model Sumarry

\begin{tabular}{|c|r|r|r|r|r|}
\hline Model & \multicolumn{1}{|c|}{$\mathrm{R}$} & R Square & $\begin{array}{c}\text { Adjusted R } \\
\text { Square }\end{array}$ & $\begin{array}{c}\text { Std. Error of the } \\
\text { Estimate }\end{array}$ & Durbin-Watson \\
\hline 1 & $.766^{\mathrm{a}}$ & .587 & .562 & .22368 & 2.118 \\
\hline
\end{tabular}

a. Predictors: (Constant), X2, X1

b. Dependent Variable: Y

Sumber: Data hasil olahan SPSS, 2016

Dari tabel model summary memperlihatkan bahwa nilai korelasi $\mathrm{R}$ sebesar 0,766 dan koefisien diterminasi $\mathrm{R}$ square sebesar 0,587 memberikan gambaran bahwa hubungan antara variabel kompensasi (X1) dan disiplin kerja (X2) terhadap kinerja karyawan section survey PT. Pama Persada tergolong kuat. Pengaruh yang dijelaskan oleh variabel kompensasi (X1) dan disiplin kerja (X2) secara bersama-sama terhadap kinerja karyawan sebesar $58.7 \%$ sisanya dijelaskan dalam variabel lain yang belum masuk dalam model penelitian. Secara partial hasil analisis regresi memperlihatkan bawa hubungan antara masing-masing variabel yang diteliti dapat dilihat dari tabel coefficients yang disajikan sebagai berikut :

\section{Tabel.6}

\section{Coefficients}

\begin{tabular}{|c|c|c|c|c|c|c|c|c|}
\hline & \multirow[b]{2}{*}{ Model } & \multicolumn{2}{|c|}{ Unstandardized Coefficients } & $\begin{array}{c}\text { Standardized } \\
\text { Coefficients }\end{array}$ & \multirow[b]{2}{*}{$\mathrm{t}$} & \multirow[b]{2}{*}{ Sig. } & \multicolumn{2}{|c|}{ Collinearity Statistics } \\
\hline & & B & Std. Error & Beta & & & Tolerance & VIF \\
\hline \multirow[t]{3}{*}{1} & (Constant) & .697 & .338 & & 2.062 & .047 & & \\
\hline & $\mathrm{X} 1$ & .059 & .071 & .097 & .833 & .411 & .920 & 1.087 \\
\hline & $\mathrm{X} 2$ & .743 & .118 & .733 & 6.286 & .000 & .920 & 1.087 \\
\hline
\end{tabular}

a. Dependent Variable: $Y$

Sumber: Data hasil olahan SPSS, 2016 
Tabel diatas memperlihatkan bahwa besarnya nilai koefisien regresi B masingmasing variabel kompensasi (X1) terhadap kinerja sebesar 0,059, disiplin kerja terhadap kinerja sebesar 0,743 dan nilai konstanta sebesar 0,697. Nilai koefisien regresi masingmasing tersebut memberikan arti bahwa setiap perubahan atau peningkatan variabel dapat menyebabkan pengaruh yang berdampak positif terhadap kinerja karyawan. Dampak positif terjadi pada variabel kompensasi (X1) dan disiplin kerja (X2). Hasil analisis yang sama dapat dilihat dari nilai koefisien standard beta masing-masing variabel yang bernilai positif. Dari ke dua variabel tersebut yang menunjukkan nilai koefisien beta terbesar adalah variabel disiplin kerja karyawan, dengan demikian dapat ditafsirkan bahwa variabel disiplin kerja karyawan berpengaruh dominan terhadap kinerja karyawan.

Berdasarkan nilai koefisien regresi masing-masing variabel tersebut, maka hubungan fungsional antara variabel independen terhadap variabel dependen dapat diformulasikan dalam persamaan regresi seperti berikut :

$\mathrm{Y}=0,697+0,059(\mathrm{X} 1)+0,743(\mathrm{X} 2)$

Persamaan tersebut dapat diartikan bahwa setiap perubahan atau peningatan masing-masing variabel independen $\mathrm{X} 1$ dan $\mathrm{X} 2$ terhadap kinerja berdampak meningkatkan nilai Y. Untuk menghasilkan estimasi yang baik maka dalam model analisis regresi tersebut perlu dilakukan evaluasi asumsi klasik dengan melihat terjadi tidaknya multikolinieritas, heteroskedastisitas dan autokorelasi. Model regresi yang baik seharusnya tidakterjadi korelasi diantara variabel independen. Ghozali (2005:91) berpendapat untuk mendeteksi terjadinya multikolinieritas dapat dilihat berdasarkan hasil Variance Inflation Factor (VIF). Nilai cutoff yang umum dipakai untuk menunjukkan adanya multikolinieritas adalah nilai-nilai toleransi $<0,10$ atau sama dengan VIF $>10$.

Berdasarkan lampiran hasil analisis coeficients dapat disajikan hasil evaluasi multikolinieritas seperti tabel di atas memperlihatkan bahwa nilai VIF masing -masing variabel indepeden yang dimasukkan kedalam model menunjukkan nilai $<10$, sehingga dapat disimpulkan tidak terjadi korelasi diantara variabel independen.

Hasil evaluasi analisis heteroskedastisitas dari tabel residual statistik dapat disajikan sebagai berikut :

Tabel.7

Residuals Statistics

Residuals Statistics ${ }^{\mathrm{a}}$

\begin{tabular}{|c|r|r|r|r|r|}
\hline & \multicolumn{1}{|c|}{ Minimum } & Maximum & Mean & Std. Deviation & $\mathrm{N}$ \\
\hline Predicted Value & 2.3027 & 3.9082 & 3.0000 & .25906 & 36 \\
Residual & -.30275 & .95376 & .00000 & .21719 & 36 \\
Std. Predicted Value & -2.691 & 3.506 & .000 & 1.000 & 36 \\
Std. Residual & -1.354 & 4.264 & .000 & .971 & 36 \\
\hline
\end{tabular}

a. Dependent Variable: $Y$

Sumber: Data hasil olahan SPSS, 2016

Menurut Ghozali (2005:95) uji eteroskedastisitas digunakan untuk menguji dalam model regresi terjadinya ketidaksamaan variance dari residual satu pengamatan ke pengamatan lain. Untuk mendeteksi ada atau tidaknya heteroskedastisitas yaitu dengan melihat penyebaran dari varian residualnya. Supranto (2000:71) berpendapat bahwa untuk mendeteksi heteroskedastisitas dapat dilihat dari nilai standard residual statistic rata-rata bernilai nol (0), sehingga error model pada analisis regresi berganda ini layak 
diasumsikan berasal dari populasi dengan variansi yang homogen, atau tidak mengalami heteroskedastisitas.

Dari tabel di atas terlihat nilai rata-rata standar variabel preditor sama dengan 0,000, sehingga dapat dinyatakan bahwa tidak adanya heterosdaskesitas. Evaluasi selanjutnya adalah melakukan pengujian terhaap penyimpangan data dengan pendekatan uji Durbin. Menurut Imam Ghozali (2005:96), pendekatan dalam masalah autokorelasi dilakukan dengan menggunakan uji Durbin - Watson (DW Test).

Berdasarkan hasil uji Durbin Watson dari hasil analisis data dapat disajikan sebagai berikut :

Tabel 8

Model Summary

\begin{tabular}{|c|r|r|r|r|r|}
\hline Model & \multicolumn{1}{|c|}{$\mathrm{R}$} & R Square & $\begin{array}{c}\text { Adjusted R } \\
\text { Square }\end{array}$ & $\begin{array}{c}\text { Std. Error of the } \\
\text { Estimate }\end{array}$ & Durbin-Watson \\
\hline 1 & $.766^{\mathrm{a}}$ & .587 & .562 & .22368 & 2.118 \\
\hline
\end{tabular}

a. Predictors: (Constant), X2, X1

b. Dependent Variable: Y

Sumber: Data hasil olahan SPSS, 2016

Tabel di atas memperlihatkan bahwa nilai Durbin Watson yang dihasilkan dari proses data adalah sebesar 2,118. Algifahri berpendapat jika nilai Durbin Waston terletak antara nilai 1,56 - 2,55 tidak terdapat adanya autokorelasi. Berdasarkan ketiga hasil evaluasi tersebut dapat disimpulkan bawa ke dua variabel yang dimasukkan dalam model regresi berganda dapat digunakan untuk mengestimasi kinerja karyawan.

1. Pengujian hipotesis penelitian

Dalam penelitian ini pembuktian hipotesis dilakukan dengan uji $\mathrm{F}$ dan uji $\mathrm{t}$. Pengujian dengan uji $\mathrm{F}$ digunakan untuk menguji hipotesis pertama yang menyatakan bahwa secara bersama-sama variabel kompensasi (X) dan disiplin kerja (X2) terhadap kinerja karyawan section survey PT. Pama Persada nusantara distrik KPC Sangatta. Sedangkan untuk membuktikan hipotesis kedua digunakan pengujian uji t untuk menguji secara partial variabel independen yang dimasukkan dalam modelpenelitian. Hasil uji $\mathrm{F}$ dari lampiran analisis data dapat dilihat pada tabel ANOVA yang disajikan sebagai berikut :

Tabel.9

ANOVA

\begin{tabular}{|c|c|c|c|c|c|c|}
\hline \multicolumn{2}{|r|}{ Model } & Sum of Squares & df & Mean Square & $\mathrm{F}$ & Sig. \\
\hline 1 & Regression & 2.349 & 2 & 1.174 & 23.475 & $.000^{\mathrm{a}}$ \\
\hline & Residual & 1.651 & 33 & .050 & & \\
\hline & Total & 4.000 & 35 & & & \\
\hline
\end{tabular}

a. Predictors: (Constant), X2, X1

b. Dependent Variable: Y

Sumber: Data hasil olahan SPSS, 2016

Tabel di atas memperlihatkan bahwa nilai signifikansi atau probabilitasnya yang menunjukkan nilai 0,000 lebih kecil dari alpha 0,05, sehingga hasil pengujian disimpulkan bahwa variabel kompensasi (X1) dan disiplin kerja (X2) berpengaruh 
signifikan terhadap kinerja karyawan PT. Pama Persada.Untuk membuktikan hipotesis kedua dilakukan dengan melihat nilai $\mathrm{t}$ dan signifikansi masing-masing variabel dari lampiran hasil uji t yang secara rinci dapat disajikan seperti berikut :

Tabel .10

Hasil uji t variabel penelitian

\begin{tabular}{|l|c|c|c|c|}
\hline \multicolumn{1}{|c|}{ Model } & $\begin{array}{c}\text { Nilai } \\
\mathrm{t} \text { hitung }\end{array}$ & $\begin{array}{c}\text { Nilai t tabel } \\
\mathrm{df}(\mathrm{n}-\mathrm{k} ; 0,05)\end{array}$ & $\begin{array}{c}\text { Nilai signifikansi } \\
\text { (Probabilitas) }\end{array}$ & $\begin{array}{c}\text { Kesimpulan } \\
\text { Hipotesis }\end{array}$ \\
\hline Kompensasi & 0.833 & 1,98 & 0,411 & $\begin{array}{c}\text { Tidak Signifikan } \\
\text { signifikan }\end{array}$ \\
Disiplin kerja & 6,286 & 1,98 & 0,000 & \\
\hline
\end{tabular}

Tabel di atas memperlihatkan bahwa nilai t hitung untuk variabel kompensasi (X1) berpengaruh tidak signifikan terhadap kinerja karyawan section survey PT Pama Persada. Hanya variabel disiplin kerja (X2) yang berpengaruh signifikan. Dari ke dua variabel tersebut nilai signifikan terkecil terletak pada variabel disiplin kerja yaitu $<0,05$, maka disimpulkan bahwa variabel disiplin kerja berpengaruh dominan terhadap kinerja karyawan.

2. Pembahasan

Berdasarkan hasil analisis regresi berganda dari tabel model summary memperlihatkan nilai korelasi sebesar 0,766 dan koefisien diterminasi sebesar 0,587. Nilai tersebut menggambarkan bahwa hubungan variabel kompensasi (X1) dan disiplin kerja (X2) secara bersama-sama berpengaruh cukup kuat terhadap kinerja karyawan. Demikian juga jika dilihat dari nilai koefisien determinasinya dapat ditafsirkan bahwa pengaruh yang dijelaskan oleh variabel kompensasi (X1) dan disiplin kerja (X2) secara bersama-sama terhadap kinerja karyawan sebesar 58,7 \%, sisanya dijelaskan oleh variabel lain yang belum masuk dalam model penelitian. Artinya variabel yang mempengaruhi kinerja karyawan Section survey PT. Pama Persada tidak terbatas dari dua variabel yang diteliti tetapi masih ada variabel lainnya yang dapat digunakan untuk mengestimasi kinerja karyawan misalnya kepemimpinan, motivasi dan lain-lain. Hasil penelitian ini menjawab permasalahan dan membuktikan hipotesis penelitian pertama sejalan dengan teori yang telah dikemukakan pada bab 2, yaitu teori dari Simamora (2004:342) yang mengatakan bahwa kinerja dipengaruhi oleh tiga faktor; pertama faktor individu terdiri dari kemampuan/keahlian, latar belakang, demografi; kedua faktor psikologis, terdiri dari presepsi, atitude, personality, pembelajaran, motivasi dan disiplin kerja; ketiga faktor organisasi, yaitu terdiri darisumber daya, kepemimpinan, penghargaan struktur dan job design. Selain Simamora, Hasibuan (2005:94) mengatakan kinerja merupakan gabungan dari tiga faktor penting, yaitu kemampuan dan minat seorang pekerja kemampuan dan penerimaan atas penjelasan delegasi tugas, serta peran dan tingkat motivasi seorang pekerja.Pembahasan secara partial dapat dijelaskan seperti berikut :

1. Variabel kompensasi (X1) berpengaruh tidak signifikan terhadap kinerja karyawan Section survey PT. Pama Persada. Keadaan ini menggambarkan bahwa kompensasi yang diberikan oleh perusahaan Pama Persada yang terdiri dari tingkat kompensasi (gaji pokok), bonus dan tunjangan lain, jaminan kesehatan /bantuan pendidikan dan asuransi, masih dalam kategori dapat memberikan dorongan kepada karyawan untuk menyelesaikan pekerjaan sesuai standar yang ditentukan oleh perusahaan. Nitisemito (1982:149-157) mengatakan bahwa masalah kompensasi bukan hanya penting karena merupakan dorongan utama seorang karyawan, tetapi masalah kompensasi ini penting juga karena kompensasi yang diberikan besar pengaruhnya terhadap semangat dan 
kegairahan kerja para karyawannya. Umar (2003:16) mengatakan bahwa cara meningkatkan kinerja pada suatu organisasi dilihat dari kompensasi dan disiplin kerja

2. Variabel disiplin kerja (X2) berpengaruh signifikan terhadap kinerja karyawan Section survey PT. Pama Persada.Hasil penelitian ini menggambarkan bahwa disiplin kerja sejalan dengan teori Ermaya (1997:128) berpenapat bahwa memahami sistem kerja dan mematuhinya berdasarkan aturan, norma yang tertulis maupun tidak tertulis secara mendalam pada diri pribadi adalah sesuatu yang harus dilakukan untuk mencapai keberhasilan tugas.

\section{DAFTAR PUSTAKA}

Aligrafi. 1997. Statitistika Induktif : Untuk Ekonomi dan Bisnis.Yogyakarta : UPP AMP YKPN

-------. 2000. Analisis Regresi : Teori, Kasus dan Solusi. Edisi Kedua. Yogyakarta : BPFE.

Amstrong, M. 1994. A Handbook of Human Resources Management. Jakarta ; Elex Media Komputindo.

Davis, Keith. 1972. Human Behaviour at Work : Human Relational Organization Behaviour. New York: Mc. Graw Hill.

Gozali, Imam. 2005. Aplikasi Analisis Multivariate dengan program SPSS. Semarang : Badan Penerbit Undip.

Hasibuan, H. Malayu. 2005. Manajemen Sumber Daya Manusia. Jakarta : Gunung Agung.

J. Supranto. 1982. Statistika Untuk Pimpinan dan Usahawan. Jakarta : Erlangga.

Mangkunegara, Anwar prabu. 2002. Manajemen Sumber Daya Manusia Perusahaan. Bandung : Remaja Rosda karya.

---------. 2005. Evaluasi Kinerja Sumber Daya Manusia. Bandung : Refika Aditama.

Ndraha, Taliziduhu. 2002. Pengembangan Sumber Daya Manusia. Jakarta : Rineka Cipta.

Robin, P. Stephen. 1996.Organizational Behaviour, Concept, Controversies and Application. Fifth Edition New Jersey : Prentice Hall.

Simamora, Henry. 2004. Manajemen Sumber Daya Manusia. Edisi Ketiga. Yogyakarta : Bagian Penerbitan STIE YKPN.

Siagian, Sondang P. 2003. Pengembangan Sumber Daya Insani. Jakarta : Gunung Agung. Spancer, Myleand Spencer. 1993. Competence at Work : Model For Supervisor.

Sugiyono. 2001. Metode Penelitian Administrasi. Bandung : Alfabeta.

Timpe, A. Dale. 2000. Produktivitas, Seri Manajemen Sumber Daya Manusia. Jakarta : Elex Media Komputindo.

Umar, Husein. 2000. Riset Sumber Daya Manusia Dalam Organisasi. Jakarta : Gramedia Pustaka Utama. 